\title{
Aktivitas Pembelajaran Guru di dalam Kelas
}

\author{
Syahra Savira Mokodompit, Icam Sutisna, Waode Eti Hardiyanti \\ Jurusan PG PAUD Fakultas Ilmu Pendidikan \\ waodeeti50@gmail.com
}

\begin{tabular}{l}
\hline Info Artikel \\
\hline Sejarah Artikel: \\
Diterima (Desember) (2019) \\
Disetujui (Januari) (2020) \\
Dipublikasikan (Januari) \\
(2020)
\end{tabular}

\section{Keywords:}

Aktivitas;

Pembelajaran; Guru; Anak Usia Dini

\begin{abstract}
Abstrak
Penelitian ini didasarkan pada metode dalam pencapaian hasil pembelajaran yang diinginkan, penetapan, dan pengembangan metode berdasarkan pada kondisi pembelajaran yang ada. Tujuan dari penelitian ini adalah untuk mengetahui bagaimana aktivitas pembelajaran guru didalam kelas di TK Mawar di Desa Sumba Kecamatan Bintauna Kabupaten Bolaang Mongondow utara Profinsi Sulawesi Utara. metode yang digunakan adalah metode penelitian kualitatif. Subyek dalam penelitian ini berjumlah 3 orang yakni guru kelas dan guru pendamping. Instrumen penelitian menggunakan wawancara, observasi, dan dokumentasi. Hasil penelitian menunjukkan bahwa aktivitas pebelajaran guru didalam kelas terdapat beberapa aspek yakni, menarik perhatian siswa, menimbulkan motivasi, memberikan acuan, memiliki sifat kreatif, memberikan perhatian dan mereview serta mengevaluasi. Ketujuh aspek tersebut belum dilakukan guru secara keseluruhan. Ada juga faktor yang mempengaruhinya yakni, latar belakang guru itu sendiri yang bukan dari sarjana pendidikan anak usia dini, serta kondisi siswa yang kurang bisa menerima arahan dari guru sehingga mereka tidak mengerti apa yang harus dilakukannya
\end{abstract}

\begin{abstract}
This research is based on methods of achieving desired learning outcomes, establishing, and developing methods based on existing learning conditions. The purpose of this study was to find out how the learning activities of teachers in the classroom at MAWAR Kindergarten in Sumba Village, Bintauna District, Bolaang Mongondow Regency, North of North Sulawesi Province. The method used is a qualitative research method. The subjects in this study amounted to 3 people namely classroom teachers and teacher assistants. Research instruments using interviews, observation, and documentation. The results showed that there are several aspects of teacher learning activities in the classroom, namely, attracting students' attention, giving rise to motivation, giving references, having a creative nature, giving attention and reviewing and evaluating. The seven aspects have not been done by the teacher as a whole. There are also factors that influence it, namely the background of the teacher himself who is not from an early childhood education degree, as well as the condition of students who are less able to receive direction from the teacher so they do not understand what to do.
\end{abstract}




\section{Pendahuluan}

Dalam kegiatan pembelajaran terdapat aktivitas mengajar guru dan aktivitas belajar peserta didik, antara aktivitas mengajar guru dan aktivitas belajar peserta didik inilah yang sering disebut interaksi pembelajaran. Adapun pengertian pembelajaran itu sendiri adalah kombinasi yang tersusun meliputi unsur-unsur manusiawi, material, fasilitas, perlengkapan dan prosedur yang saling mempengaruhi untuk mencapai tujuan pembelajaran (Gerry \& Kingsley dalam Snelbecker, 1980 : 12). guru harus memiliki strategi agar anak didik dapat belajar secara efektif dan efisien, mengena pada tujuan yang diharapkan. Sebagai seorang tenaga pendidikan guru harus dapat menguasai keadaan kelas sehingga tercipta suasana belajar yang menyenangkan, untuk menghasilkan proses pembelajaran yang berkualitas, seorang guru membutuhkan metode pembelajaran yang baik pula, yang mampu memberikan dampak positif terhadap hasil belajar siswa, sehingga dibutuhkan kemampuan guru dalam menerapkan metode pembelajaran yang sesuai dengan karakteristik peserta didiknya (Roestiyah, 1989)

Guru sebagai pembimbing diharapkan mampu menciptakan kondisi yang strategi yang dapat membuat peserta didik nyaman dalam mengikuti proses pembelajaran tersebut. Dalam menciptakan kondisi yang baik, hendaknya guru memperhatikan dua hal: pertama, kondisi internal merupakan kondisi yang ada pada diri siswa itu sendiri, misalnya kesehatan, keamanannya, ketentramannya, dan sebagainya. Kedua, kondisi eksternal yaitu kondisi yang ada di luar pribadi manusia, umpamanya kebersihan rumah, penerangan serta keadaan lingkungan fisik yang lain. Untuk dapat belajar yang efektif diperlukan lingkungan fisik yang baik dan teratur, misalnya ruang belajar harus bersih, tidak ada bau-bauan yang dapat mengganggu konsentrasi belajar, ruangan cukup terang, tidak gelap dan tidak mengganggu mata, sarana yang diperlukan dalam belajar yang cukup atau lengkap (Hadari Nawawi, 1989: 117).

Tujuan Pendidikan Anak Usia Dini (PAUD) menurut Undang-Undang nomor 20 tahun 2003 tentang sistem pendidikan nasional dinyatakan bahwa pendidikan anak usia dini adalah sebagai suatu upaya pembinaan yang ditujukan kepada anak sejak lahir sampai dengan usia enam tahun yang dilakukan melalui pemberian rangsangan 
pendidikan untuk membantu pertumbuhan dan perkembangan jasmani dan rohani agar anak memiliki kesiapan dalam memasuki pendidikan lebih lanjut (Indonesia, 2003).

Penilaian kelas merupakan suatu kegiatan yang dilakukan guru yang berkaitan dengan pengambilan keputusan tentang pencapaian kompetensi dasar setelah mengikuti proses pembelajaran. Data yang diperoleh pendidik dalam pembelajaran berlangsung dijaring dan dikumpul melalui prosedur dan alat penilaian yang sesuai dengan kompetensi dasar atau indicator yang akan dinilai. Penilaian hasil belajar baik formal maupun informal diadkan dalam suasana yang menyenangkan, sehingga memungkinkan peserta didik menunjukkan apa yang dipahami dan mampu dikerjakannya. Hasil belajar seorang peserta didik dalam periode waktu tertentu dibandingkan dengan hasil yang dimiliki peserta didik tersebut sebelum mengikuti proses pembelajaran, dan dianalisis apakah ada peningkatan kemampuan. Jika peserta didik tidak terjadi peningkatan signifikan, maka guru memunculkan pertanyaan. Tingkat kemampuan seorang peserta didik tidak dianjurkan untuk dibandingkan dengan peserta didik lainnya. Hal itu untuk menghindari peserta didik merasa rendah diri dan dihakimi oleh pendidik. Para pendidik justru harus membantu untuk mencapai kompetensi atau indicator para peserta didik yang diharapkan. kelas pada dasarnya merupakan rangkaian kegiatan pendidik yang terkait dengan pengambilan keputusan tentang pencapaian kompetensi atau hasil belajar siswa selama mengikuti proses pembelajaran.

Dari proses assessment ini, pendidik akan memperoleh potret atau profil kemampuan peserta didik da lam mencapai sejumlah standar kompetensi dan kompetensi dasar yang dirumuskan dalam KTSP masing-masing sekolah. Dalam melaksanakan penilaian kelas, anda harus paham bahwa penilaian kelas merupakan suatu proses yang dilakukan melalui langkah-langkah perencanaan, penyusunan alat penilaian, pengumpulan informasi melalui sejumlah bukti untuk menunjukkan pencapaian hasil belajar peserta didik. Penilaian kelas dilaksanakan dalam berbagai teknik, seperti penilaian untuk kerja (performance), penilaian sikap, penilaian tertulis, (paper and pencil test)< penilaian proyek, penilaian produk, penilaian melalui kesimpulan hasil kerja peserta didik (portofolio), dan penilaian diri (self assement). Dalam melaksanakan pembelajaran, selalu saja ditemukan berbagai kelemahan, baik dari segi perencanaan, pelaksanakan maupun penilaiannya. Sebaik apapun cara 
mengajar selalu ada kelemahan di sana-sini. Tentu saja, seiring dengan pengalaman yang dimiliki, hendaknya semakin sedikit kelemahan yang dilakukan. Jangan sampai melakukan kesalahan yang sama pada pembelajaran berikutnya. Oleh karena itu, belajar dari kesalahan untuk menjadikannya sebagai bahan perbaikan adalah sebuah langkah yang bijaksana . tanpa adanya refleksi. Tidak mudah untuk mengetahui bagianbagian atau aspek-aspek mana dari pembelajaran yang telah dilakukan masih salah atau lemah. Kadang-kadang guru menganggap atau bahkan meyakini bahwa apa yang telah dilakukan selama ini merupakan aktivitas pembelajaran yang baik dan benar. Pembelajaran yang dilakukannya selama ini dianggap sebagai ritual yang harus dilakukan. Sebuah pakem yang harus diikuti, sehingga tidak perlu dianalisa dan dikritisi. (Uno, dan Koni, 2013)

Penelitian yang telah dilakukan di TK MAWAR Desa Sumba Kecamatan Bintauna Kabupaten Bolaang Mongondow Utara Profinsi Sulawesi Utara. Penelitian dilakukan setiap minggu 2 kali pertemuan selama 1 bulan, Penulis menemukan fakta bahwa pembelajaran guru kurang menarik dan kurang kreatif sehingga saat melakukan pembelajaran ada beberapa guru kurang pahama dalam membuat kerajinan dan pada saat guru memberikan pembelajaran masih terdapat siswa bermain sendiri dan guru hanya mebiarkan dan memberikan respon biasa saja, guru juga kurang mampu menimbulkan minat serta memusatkan perhatian terhadap siswa. Guru kurang disiplin waktu seperti saat penulis sedang melakukan penelitian biasanya siwa sudah tiba lebih awal dari guru. Guru kurang memberikan dorongan terhadap siswa untuk mengikuti kegiatan pembelajaran dan Aktivitas guru di dalam kelas juga kurang memotivasi siswa, padahalah untuk Memotivasi siswa guru bisa melakukannya dengan cara menimbulkan kehangatan dan keantusiasan, menimbulkan rasa ingin tahu, mengemukakan ide, serta memperhatikan minat anak sehingga guru mengetahui tingkat keberhasilan pencapaian siswa. Dari pemaparan di atas, fokus masalah yang akan di teliti bagaimana aktivitas pembelajaran guru di dalam kelas adalah : (1) guru kurang kreatif dalam memberikan pembelajaran (2) guru kurang memberikan respon dan perhatian terhadap siswa (3) guru kurang disiplin waku.

Untuk dapat mencapai tujuan yang di harapkan, yakni aktivitas pembelajaran guru di dalam kelas pada khususnya guru di TK MAWAR Desa Sumba Kecamatan Bintauna Kabupaten Bolaang Mongondow Utara Profinsi Sulawesi Utara, kepala sekolah 
dan guru dapat bekerja sama dengan baik untuk merancang kegiatan pembelajaran didalam kelas agar dapat menarik perhatian siswa dan dapat memotivasi juga menanamkan nilai disiplin. Guru juga harus kreatif dan memberikan perhatian lebih terhadap perkembangan siswa agar keberhasilan siswa tercapai dengan baik. Dengan demikian, tujuan dari aktivitas pembelajaran guru di dalam kelas dapat dikuasai oleh guru dan bermanfaat untuk guru dimasa sekarang dan dimasa yang akan datang.

Manfaat pada penelitian ini terdiri atas manfaat Teoretis dan manfaat praktis. Penelitian ini diharapkan dapat menambah ilmu dan wawasan bagi penulis maupun pembaca tentang aktivitas pembelajaran guru di dalam kelas. Penelitian ini juga dapat bermanfaat sebagai pengembangan ilmu pendidikan dalam mencapai tujuan pembelajaran yang optimal. Manfaat praktis yang diharapkan dari penelitian ini adalah sebagai berikut:. (1) Bagi Peneliti penelitian ini dapat memberikan gambaran dan wawasan yang baik kedepannya ketika menjadi seorang pengajar, yakni dapat mengetahui bagaimana aktivitas pembelajaran guru di dalam kelas. (2) Bagi Guru Penelitian ini dapat dijadikan masukan bagi guru tentang bagaimana aktivitas pembelajaran guru di dalam kelas.

\section{Metode Penelitian}

Jenis penelitian

Dalam penelitian ini penulis menggunakan metode penelitian kualitatif. Alasan peneliti menggunakan metode penelitian kualitatif dalam penelitian ini, dikarenakan penelitian yang penulis lakukan merupakan penelitian terhadap kondisi obyek yang alamiah, tentang situasi sosial di kelas yakni permasalahan mengenai aktivitas pembelajaran guru di dalam kelas di TK MAWAR. sebagaimana menurut Sugiyono (2013: 15) penelitian kualitatif adalah penelitian yang berlandaskan pada filsafat post poitivisme, diguakan untuk meneliti pada kondisi objek yang ilmiah, (sebagai lawannya eksperimen) dimana peneliiti adalah sebagai instrumen kunci, pengambilan sampel sumber data dilakukan secara purposive dan snowball, teknik pengumpulan dengan triangulasi (gabungan), analisis data bersifat induktif atau kualitatif, dan hasil penelitian kualitatif lebih menekakan makna daripada generelasi. 
Waktu dan Tempat Penelitian

Penelitian dilakukan dibulan Oktober sampai dengan bulan November. Lokasi dalam penelitian ini dilakukan di TK MAWAR yang beralamat di Desa Sumba Kecamatan Bintauna Kabupaten Bolaang Mongondow Utara Profinsi Sulawesi Utara.

Subjek Penelitian

Penelitian kualitatif fokusnya adalah manusia dan interaksinya dalam konteks sosial. Subyek dalam penelitian ini adalah guru di sekolah TK MAWAR yang berjumlah 3 orang yakni guru kelas dan guru pendamping.

Prosedur

Penelitian dilakukan dengan cara meneliti bagaimana aktivitas pembelajaran guru didalam kelas, yaitu dengan melakukan interaksi dalam konteks sosial.

Data, Intrumen, dan Teknik Pengumpulan Data

Teknik dan alat pengumpulan data yang digunakan dalam penelitian ini adalah teknik observasi langsung dengan alat panduan observasi, teknik komunikasi langsung dengan alat panduan wawancara, dan teknik dokumenter dengan alat dokumentasi.

Teknik Analisis Data

Analisis data pada penelitian kualitatif dilakukan pada saat pengumpulan data berlangsung dan setelah selesai pengumpulan data pada periode tertentu. Sebagaimana menurut Miles dan Huberman (dialihbahasakan oleh Rohidi, 1992:15-16) mengemukakan, "Aktivitas dalam analisis data kualitatif dilakukan secara interaktif dan berlangsung secara terus menerus sampai tuntas, sehingga datanya sudah jenuh. Aktifitas dalam analisis data terdiri atasdata collection, data reduction, data display, dan conclusion drawing/verification."

\section{Hasil Penelitian dan Diskusi}

Sesuai dengan hasil penelitian yang di lakukan di sekolah TK MAWAR yang berada di Desa Sumba Kecamatan Bintauna Kabupaten Bolaang Mongondow Utara Profinsi Sulawesi Utara.

Minggu ke-1 Senin, 21 Oktober 2019 
Pada saaat melakukan penelitian, peneliti tiba di sekolah TK MAWAR pukul 07:00 guru di sekolah TK MAWAR sedang melakukan pembersihan kelas seperti menyapu ruang kelas, mengatur kursi dan meja, mengganti air tempat cuci tangan siswa dan menyapu depan kelas. Setelah itu bebrapa siswa sudah mulai berdatangan, setiap siswa yang datang guru menyambut dengan baik dapenuh dengan keceriaan, setelah itu guru mengarahkan siswa untuk berbaris rapi didepan kelas, sebelum masuk guru mengajak siswa untuk berdoa dan berjabat tangan sebelum masuk kelas. Kemudian pada saat membuka kegiatan pembelajaran guru mengajak siswa untuk berdoa terlebih dahulu setelah itu memulai kegiatan pembelajaran pada saat penulis sedang melakukan penelitian mereka belajar mewarnai pola hitam putih, ada beberapa guru yang hanya memberikan pensil warna/crayon dan pola kepada anak lalu dibiarkan siswa mewarnai dan guru meninggalkan kelas dan pergi ke ruang guru dan guru yang lain melanjutkan kegiatan mereka seperti menulis tanpa memperhatikan siswa yang sedang diberikan tugas. Seharusnya jika siswa sedang mengerjakan tugas guru harus tetap berada di samping siswa dan memberikan perhatian kepada siswa seperti menanyakan daun warna apa, bunga matahari warna apa, agar anak lebih mudah untuk mengerti sebagaimana menurut Undang-undang Republik Indonesia Nomor 20 tahun 2003 tentang Sistem Pendidikan Nasional, bahwa pembelajaran adalah proses interaksi pendidik dengan peserta didik dan sumber belajar yang berlangsung dalam suatu lingkungan belajar. Setelah itu memasuki jam makan guru-guru mengarahkan siswa untuk membersihkan alat tulis menulis, mencuci tangan dan duduk rapi lalu membaca doa sebelum makan, saat siswa sudah selesai makan guru mengajak anak untuk cuci tangan dan merapikan meja. Setelah itu mereka bermain dengan permainan yang sudah di sediakan oleh sekolah, namun peneliti heran kenapa pada saat dimulai jam pelajaran sampai sudah pada kegiatan bermain guru tidak mengajak siswa untuk bernyanyi setelah ditanyakan kepada salah satu guru katanya ada seorang guru yang biasa mengajarkan bernanyi tidak hadir karena kurang sehat dan setelah peneliti Tanya lagi guru yang lain alasannya mereka kurang percaya diri untuk bernyanyi di depan anakanak, padahal semua guru PAUD harus bisa menagajarkan lagu anak-anak untuk siswa. Kemudan setelah kegiatan bermain selesai guru menyiapkan siswa untuk pulang sebelum keluar kelas guru mengajak siswa untuk berdoa stelah itu keluar kelas. Pada penelitian ini peneliti mengidentifikasi masalah yaitu guru kurang memiliki 
keterampilan seni dan kurang percaya diri sehingga proses pembelajaran kurang bekesan terhadap siswa.

Selasa, 22 Oktober 2019

Hari kedua peneliti tiba di sekolah seperti jam kemarin yaitu pukul 07:00 pagi saat penulis tiba ada beberapa siswa sudah berdatangan tetapi kelas masih terkunci karena gurunya belum tiba disekolah, seharusnya guru yang harus tiba lebih awal dari siswa. beberapa saat kemudian kelas sudah terbuka dan guru langsung membersihkan ruang kelas, mengganti air tempat cuci tangan siswa dan menyapu di depan kelas. kegiatan belajar mengajar dimulai dengan pembukaan pertama guru mengajarkan siswa untuk membacaca doa terlebih dahulu lalu mereka menyanyikan 2 lagu anak dan langsung pada kegiatan belajar, saat saya sedang melakukan penelitian pada hari kedua minggu pertama mereka belajar menggambar bentuk pola segi tiga, lingkaran dan persegi empat. Pada saat siswa sedang melakukan kegiatan menggambar pola guru mendampingi dan membantu siswa dengan cara memperhatikan bentuk yang di gambar dan menunjukkan bahwa bentuk pola seperti pada gambar. Saat kegiatan belajar selesai guru langsung mengarahkan siswa untuk merapikan meja lalu mencuci tangan karena sudah waktu untuk makan, sebelum makan mereka di ajarkan untuk membaca doa terlebih dahulu dan membaca doa ketika sudah selesai makan. Kegiatan selanjutnya mereka langsung pada kegiatan bermain setelah kegiatan bermain mereka melanjutkan pada kegiatan belajaer seperti membaca doa lalu setelah kegiatan belajar selesai guru langsung mengarahkan siswa untuk membersihkan alat tulis dan merapikan meja, dan tidak lupa untuk membaca doa sebelum pulang sekolah. Saat sedang melakukan penelitian, penilti menemukan fakta bahwa guru yang berada di TK mawar kurang disiplin terutama disiplin waktu karena setiap lembaga pendidikan baik lembaga formal maupun informal pasti memiliki peraturan-peraturan yang harus dipatuhi oleh setiap ketua ataupun anggotanya, begitu juga dengan lembaga lainnya. Setiap sekolah memiliki peraturan-peraturan yang harus dipatuhi oleh kepala sekolah, guru ataupun para peserta didik, baik itu peraturan tentang tanggung jawab, ketegasan dalam belajarmengajar ataupun dalam menggunakan waktu.

Minggu Ke-2 Senin, 28 Oktober 2019 
Pukul 07:00 pagi peneliti sudah tiba disekolah dengan beberapa orang guru dan siswa, kelas sudah rapi dan bersih. Pukul 07:30 guru mengarahkan siswa untuk berbasris di depan kelas lalu masuk dalam kelas dengan berjabatangan dengan guru, sebelum melakukan kegiatan belajar mengajar guru mengajak siswa untuk berdoa terlebih dahulu setelah itu men yanyikan lagu anak dan masuk pada kegiatan belajar dengan menggunakan pembelajaran sesuai dengan tema, mereka melakukan kegiatan meronceh, pada saat kegiatan belajar sedang berlangsung guru kurang aktiv dalam kegiatan tersebut, mereka hanya memberikan alat dan bahan kepada siswa lalu mereka sibuk menulis dan guru lainnya hanya duduk diam di meja guru, seharusnya dalam kegiatan pembelajaran tersebut guru harus mendampingi anak karena Pembelajaran yang kurang memperhatikan perbedaan individual anak dan didasarkan pada keinginan guru, akan sulit untuk dapat mengantarkan anak didik ke arah pencapaian tujuan pembelajaran. Setelah kegiatan meronceh selesai guru langsung mengarahkan anak untuk membersihkan kursi dan meja lalu mencuci tangan untuk persiapan makan, sebelum makan guru mengajak siswa untuk berdoa terlebih dahulu setelah selesai makan guru juga mengajak siswa untuk membaca doa sesudah makan. Lalu mereka lanjut pada kegiatan bermain sampai pada akhir pembelajaran guru mengarahkan siswa untuk merapikan alat tulis dan duduk rapi, sebelum keluar kelas guru mengajak siswa untuk membaca doa setelah itu keluar kelas dengan rapid an berjabat tangan. saat siswa sudah pulang sekolah guru kembali membersihkan dan merapikan ruang kelas. Pada penelitian ini Guru kurang memberikan dorongan terhadap siswa untuk mengikuti kegiatan pembelajaran dan Aktivitas guru di dalam kelas juga kurang memotivasi siswa, padahalah untuk Memotivasi siswa guru bisa melakukannya dengan cara menimbulkan kehangatan dan keantusiasan, menimbulkan rasa ingin tahu, mengemukakan ide, serta memperhatikan minat anak sehingga guru mengetahui tingkat keberhasilan pencapaian siswa.

Selasa, 29 Oktober 2019

Pada saat peneliti tiba di sekolah kelas sudah terbuka dan guru sedang mebersihkan dan merapikan ruang kelas lalu menyapu di depan kelas, beberapa saat kemudian siswa sudah mulai berdatangan di antar oleh orang tua masing-masing. Pukul 07:30 guru mengarahkan siswa untuk berbaris yang rapi di depan kelas, sebelum masuk mereka membaca doa dan berjabat tangan dengan guru. Saat sudah berada di 
dalam kelas guru mengajak siswa untuk membaca doa dan menyanyikan lagu anak dan masuk pada kegiatan inti, saat mereka sedang melakukan kegiatan inti peneliti bertanya kepada salah satu guru mengenai kreativitas di dalam kelas seperti hasil karya guru, seperti media pembelajaran yang dibuat sendiri oleh guru dapat dilihat di kelas yang sebagian ditempel pada dinding kelas ternyata guru kurang kreatif sehingga mereka hanya mebeli semua alat dan kerajinan yang tertampal di dalam ruang kelas seharusnya guru itu harus kreatif karena Peran guru dalam pembelajaran aktif yang sangat utama adalah memfungsikan dirinya sebagai fasilitator, yang dapat dapat membantu peserta didik untuk belajar dan memiliki keterampilan-keterampilan yang diperlukan untuk mencapai tujuan pembelajaran.. Setelah kegiatan inti berakhir guru mengajak siswa untuk mencuci tangan dan makan, sebelum makan mereka membaca doa terlebih dahulu dan setelah makan membaca doa sesudah makan, setelah itu mereka melanjutkan bermain, saat kegiatan bermain selesai guru mengarahkan siswa untuk duduk rapi lalu berdoa dan berjabat tangan dengan guru sebelum keluar kelas. Dari hasil penelitian ini peneliti menemukan fakta bahwa guru kurang kreatif sehingga guru tidak dapat menciptakan sesuatu yang mengenai kreativitas didalam kelas, padahal Guru kreatif adalah guru yang mampu menggunakan berbagai pendekatan dalam proses belajar mengajar dengan cara inovatif dan efektif dalam membimbing peserta didiknya. Untuk menciptakan pembelajaran yang kreatif dan menyenangkan, diperlukan berbagai ketrampilan mengajar, seperti ketrampilan bertanya, memberi penguatan, mengadakan variasi, menjelaskan, membuka dan menutup pelajaran. Guru harus menjadi contoh bagi anak khususnya dalam pengembangan kreativitas karena guru yang kreatif akan mengasilkan anak didik yang kreatif pula. Kreatifitas guru berperan dalam memenuhi kebutuhan belajar anak yang dimuat dalam kurikulum dan sesuai tahap perkembangannya. Keterampilan mengajar tidak terlepas dari kreativitas guru dalam perencanaan pembelajaran, strategi pembelajaran, dan proses pembelajaran. Berdasarkan hasil penelitian dan pembahasan dapat disimpulkan bahwa salah satu upaya untuk meningkatkan kompetensi pedagogik guru adalah dengan meningkatkan kreativitasnya.

Minggu ke-3 Senin, 04 November 2019

Pukul 07:30 siswa sudah berbaris rapi di depan kelas dan guru mengajak siswa membaca doa, sebelum masuk kelas siswa berjabat tangan dengan guru. Saat sudah di 
dalam kelas guru mengajak siswa untuk membaca doa, lalu menyanyikan lagu anak. Namun, pada saat guru mengajak anak seperti membaca doa atau bernyanyi guru kurang semangat sehingga siswa tidak terfokus pada kegiatan tersebut. Pada saat kegiatan belajar sedang berlangsung guru kurang memperhatikan siswa sehingga pada saat pembelajaran ada beberapa siswa hanya bermain di luar kelas dan guru hanya membiarkan alasannya siswa tersebut akan tetap masuk kelas, Padahal guru harus memperhatikan hal tersebut karena Keberhasilan dalam proses pembelajaran di kelas memang tidak semata tergantung guru, tetapi melibatkan banyak faktor, diantaranya keaktifan siswa, tersedianya fasilitas belajar, kenyamanan dan keamanan ruangan kelas dan beberapa faktor lainnya, kendati memang keberadaan guru merupakan faktor penentu dalam menciptakan kondisi pembelajaran yang efektif. Setelah itu guru mengarahkan siswa untuk cuci tangan dan duduk rapi untuk makan, sebelum makan guru mengajak siswa untuk membaca doa terlebih dahulu, setelah makan guru mengajak siswa untuk membaca doa sesudah makan dan mengembalikan tempat makan ke dalam tas masing-masing. Kemudian mereka lanjut pada kegiatan bermain, setelah itu guru mengarahkan siswa untuk membersihkan permainan dan duduk rapi, sebelum keluar kelas guru mengjak siswa untuk membaca doa dan berjabat tangan.

Dalam penelitian terdapat bahwa guru harus memberikan perhatian terhadap siswa sebagai motivasi belajar, sebab sebuah perhatian dari seorang guru mempunyai peranan penting dalam sebuah pembelajaran. Hal ini dapat menumbuh kembangkan motivasi belajar peserta didik.

Selasa, 05 November 2019

Pukul 07:00 pagi peneliti sudah berada di sekolah, kelas masih terkunci dan belum ada guru dan siswa, bebrapa menit kemudian siswa sudah mulai berdatangan yang diantar orang tua masing-masing. Sudah pukul 07:30 guru sudah datang dan membuka pintu kelas lalu membersihkan ruang kelas, merapikan kursi dan meja, mengganti air tempat cuci tangan dan menyapu di depan kelas, pukul 08:00 guru mengarahkan siswa untuk berbaris rapi di depan kelas dan mengajak siswa untuk berdoa, sebelum masuk kelas siswa berjabat tangan dengan guru. Saat sudah berada di dalam kelas guru mengajak siswa untuk duduk rapi lalu membaca doa dan menyanyikan lagu anak, masih seperti biasa guru kurang aktif dan kurang semangat 
dalam memberikan pembelajaran kepada siswa. Setelah itu mereka masuk pada kegiatan belajar menggunting dan menempel, guru membagikan kertas, gunting, dan lem kepada siswa dan kembali kemeja guru sambil melihat siswa dari kejauhan. Sehingga ada beberapa siswa yang belum selesai mengerjakan karena kurang paham. Padahal guru harus berada di samping siswa pada saat memberikan pembelajaran apalagi saat menggunakan benda seperti gunting. Setelah itu mereka masuk pada kegiatan bermain, pada saat melakukan kegiatan bermain guru kurang memperhatikan siswa sehinga ada siswa yang berkelahi sampai melaporkan kepada orang tua sehingga guru di salahkan. Setelah kegiatan bermain selesai guru mengarahkan siswa untuk duduk rapi dan membaca doa sebelum keluar kelas. Dalam jenjang pendidikan usia dini, guru juga berperan sebagai pengasuh, termasuk dalam kegiatan bermain anak. Karena pada dasarnya anak adalah sosok individu yang masih bergantung pada orang dewasa untuk melakukan kegiatan dalam hidupnya (mencoba mandiri dan mengontrol dirinya sendiri). Maka mereka membutuhkan peran pengasuh termasuk dalam kegiatan bermain mereka. Ketika anak menangis karena bertengkar saat bermain (belum mampu mengontrol diri sendiri), maka guru juga berperan sebagai pendamai dan penasehat. Dimana seorang guru membantu anak didik dalam menyelesaikan konflik yang terjadi dengan menawarkan cara penyelesaian tanpa menimbulkan pertikaian dan juga menasehati mereka untuk saling memaafkan. Dengan tujuan, jika nanti terjadi konflik atau permasalahan lagi, anak mampu menyelesaikannya dengan baik (tanpa pertikaian).

Minggu ke-4 Senin, 11 November 2019

Pada saat tiba di sekolah kelas sudah terbuka halaman kelas dan ruang kelas sudah bersih dan rapi. Pukul 07:30 siswa sudah berbaris rapi, sebelum masuk kelas siswa membaca doa terlebih dahulu dan berjabat tangan dengan guru. Saat sudah di dalam kelas guru mengajak siswa untuk duduk rapi dan membaca doa, setelah itu guru mengajak siswa untuk bernyanyi lagu anak. pada minggu ke-4 hari pertama mereka melakukan pembelajaran membuat kreativitas membuat boneka panda, saat melakukan kegiatan tersebut guru kurang kreatif sehingga pada saat memberikan pembelajaran tersebut ada guru tidak tahu membuat boneka panda dan hanya ada satu orang guru yang bias sehingga hanya 1 orang guru yang mendampingi siswa saat melakukan pembelajaran tersebut. Setelah itu guru mengarahkan siswa untuk mencuci tangan 
untuk makan, sebelum makan guru mengajak siswa untuk membaca doa, saat siswa sedang makan ada seorang siswa yang tidak mebawa bekal tetapi guru hanya membiarkan siswa tersebut bermain sendiri, padahal guru harus memperhatikan hal tersebut dengan cara ajari siswa untuk saling berbagi. setelah makan guru megarahkan siswa untuk mencuci tangan dan membaca doa sesudah makan dan lanjut pada kegiatan bermain. Setelah itu guru mengajak siswa untuk duduk rapi dan membaca doa sebelum keluar kelas. Pada penelitian ini guru kurang menanamkan keterampilan saling peduli/ berbagi terhadap siswa, Keterampilan ini perlu ditanamkan pada anak didik kita secara terus menerus, dengan cara seorang guru harus mampu mengkondisikan anak didik pada keadaan yang memang mereka harus saling berbagi, setia kawan dan tolong menolong, guru bisa menerapkan ini dalam pembelajaran-pembelajarannya dikelas ataupun diluar kelas. Guru memperkenalkan dan memberikan arahan pada anak didik kita tentang betapa pentingnya keterampilan saling berbagi ini untuk dikuasai khususnya diterapkan dalam kehidupannya dimasyarakat luas.

Selasa, 12 November 2019

Pukul 07:30 peneliti tiba disekolah, guru sedang mengarahkan siswa untuk berbaris rapi di depan kelas. Sebelum masuk kelas guru mengajak siswa untuk berdoa terlebih dahulu dan berjabat tangan. saat di dalam kelas guru mengajak siswa untuk berdoa dan bernaynyi lagu anak lalu lanjut pada kegiatan belajar, mereka melakukan pembelajaran mebuat perahu dari kertas lipat. Saat melakukan kegiatan tersebut guru mendampingi siswa tapi bukan terfoku pada siswa guru hanya sibuk bercerita padahal seorang guru merupakan contoh bagi siswa, seharusnya saat kegiatan belajar sedang berlangung guru harus memperhatiakn siswa. Setelah kegiatan belajar selesai guru langsung mengarahkan siswa untuk membersihkan alat tulis dan mencuci tangan untuk makan, sebelum makan guru mengajak siswa untuk berdoa terlebih dahulu, setelah selesai makan guru menajak siswa unyuk beroda sesudah makan. Setelah itu mereka lanjut pada kegiatan bermain, saat kegiatan bermain sedang berlangsung guru membiarkan siswa bermain sendiri dan guru berkumpul di ruang guru padahal guru harus tetap mengawasi siswa agar tidakterjadi hal yang tidak diinginkan.

Pukul 10:30 guru mengarahkan siswa untuk duduk rapi dan mengajak siswa untuk membaca doa dan berjabat tangan sebelum keluar kelas. 
Hasil ini penelitian ini terdapat bahwa kurangnya perhatian guru terhadap siswa, seharusnya guru tidak boleh meninggalkan siswa saat masih kegiatan belajar mengajar karena seorang guru diharapkan dapat menjadi subjek pembelajaran yang sesungguhnya, yang dapat berinteraksi langsung dengan peserta didiknya yaitu dengan memberi sebuah perhatian baik berupa nasihat, pujian, maupun gurauan.

\section{Simpulan}

Secara umum dapat disimpulkan bahwa aktifitas guru didalam kelas kurang kreatif dan kurang memberikan perhatian kepada siswa sehingga guru tidak mengetahui tingkat kecerdasan siswa, guru juga masih kurang mampu meminta anak untuk mengekspresikan pendapat anak sendiri, sehingga guru tidak mengetahui tingkat keberhasilan siswa pada saat mengikuti pelajaran. Guru juga kurang disiplin kepada siswa karena masih ada siswa yang asik bermain sendiri saat kegiatan belajar sedang berlangsung sehingga belum bisa menerima dengan baik apa yang disampaikan oleh guru.

\section{Daftar Pustaka}

Aprida Pane dan Muhammad Darwis Dasopang. (2017). Belajar Dan Pembelajaran. Jurnal Kajian Ilmu-ilmu Keislaman Vol. 03 No. 2 Desember 2017.

Mardiah Kalsum Nasution. (2017). Penggunaan Metode Pembelajaran Dalam Peningkatan Hasil Belajar Siswa. Jurnal Ilmiah Bidang Pendidikan Vol. 11, No. 1, 2017; ISSN 1978-8169.

Sunhaji. (2014) Konsep Manajemen Kelas Dan Implikasinya Dalam Pembelajaran. Jurnal kependidikan.

Fakhrurrazi. (2018). Hakikat Pembelajaran Yang Efektif. Jurnal At-Tafkir Vol. XI No. 1 Juni 2018.

Raehang. (2014). Pembelajaran Aktif Sebagai Induk Pembelajaran Koomperatif. Jurnal Al-Ta'dib Vol. 7 No. 1 Januari-Juni 2014.

Feditat Acistamaya. (2017). Peran Guru dalam Kegiatan Bermain Anak. Diakses tanggal 6 November 2017 dari https://www.kompasiana.com/feditatacistamaya/59ff9cf2c252fa360b6c2c62/pe ran-guru-dalam-kegiatan-bermain-anak?page=all

Rahma Seftiarani dkk. (2016). Kreativitas Guru Dan Kompetensi Pedagogik Di Paud Kecamatan Penengahan.

Syarifah Aini. (2017). Pengaruh Kedisiplinan Guru Terhadap Karakter Siswa Dalam Belajar Di Madrasah Tsanawiyah Al-Washliyah Ismailiyah No. 82 Medan. 
Uno, Hamzah B dan Koni, Satria. (2013) Assesment Pembelajaran. (Ed) Dewi Ipurwanti. Jakarta : Bumi AksaraErikson. 1967, Bermain dan permainan anak: tanggerang selatan, Universitas terbuka

Ahmad Nasihaddin, 2016. Meningkatkan mororik halus anak melalui kegiatan melipat dengan berbagai media pada abak kelompok B3 di TK ABA karang malang. 